\title{
PELAKSANAAN SUPERVISI KEPALA SEKOLAH TERHADAP KINERJA GURU KELAS DI SDN UWEDIKAN KECAMATAN LUWUK TIMUR
}

\author{
Oleh : \\ Hasrat Aimang \\ Email : hasratsambeabut@yahoo.com
}

\begin{abstract}
Abstrak
Penelitian ini bertujuan untuk mendapatkan keterangan tentang bagaimana Pelaksanaan Supervisi Kepala Sekolah Terhadap Kinerja Guru Kelas di SDN Uwedikan Kecamatan Luwuk Timur dan sebagai bahan penelitian lebih lanjut serta lebih mendalam tentang pelaksanaan supervisi kepala sekolah dalam mewujudkan mutu pendidikan. Dalam penelitian ini diterapkan metode analisis kuantitatif dengan pendekatan yang bersifat sosiologis / empiris, dengan maksud hanya sekedar memberikan gambaran dari masalah Pelaksanaan Supervisi Kepala Sekolah Terhadap Kinerja Guru Kelas di SDN Uwedikan Kecamatan Luwuk Timur. Hal ini ditentukan oleh adanya peran yang baik dari Kepala Sekolah dengan menjalankan semua fungsi dan tugasnya sebagai pemimpin (leadership) serta sebagai pengelola (manajerial) di SDN Uwedikan, sehingga mutu pendidikan di sekolah tersebut menjadi semakin baik sesuai dengan tujuan yang diharapkan dan adanya program-program peningkatan propesionalisme guru serta penunjang mutu pendidikan yang diselenggarakan Kepala Sekolah di SDN Uwedikan Kecamatan Luwuk Timur.

Berdasarkan hasil penelitian yang telah dipaparkan mengenai Pelaksanaan Supervisi Kepala Sekolah Terhadap Kinerja Guru Kelas di SDN Uwedikan Kecamatan Luwuk Timur yang di tinjau dari dua aspek kemudian penulis jabarkan dalam tabel berikut yang hasilnya merupakan kesimpulan dari keseluruhan aspek yang dikaji mengenai Pelaksanaan Supervisi Kepala Sekolah Terhadap Kinerja Guru Kelas di SDN Uwedikan Kecamatan Luwuk Timur adalah tergolong "sangat memuaskan" dengan perolehan skor 3,80. Skor tersebut memberi makna bahwa $95,125 \%$, atau 5 orang dari 6 responden menyatakan bahwa pelaksanaan supervisi kepala sekolah terhadap guru kelas di SDN Uwedikan Kecamatan Luwuk Timur adalah "sangat memuaskan"
\end{abstract}

Kata kunci : supervisi, kinerja

\section{PENDAHULUAN}

Pada dasarnya guru memiliki potensi yang cukup tinggi untuk berkreasi dan meningkatkan kinerja, namun banyak faktor yang menghambat mereka dalam mengembangkan berbagai potensi secara optimal. Oleh karena itu, sangat dirasakan perlunya pembinaan yang kontinyu dan berkesinambungan dengan program yang terarah dan sisitematis terhadap para guru dan personil pendidikan lainnya di sekolah. Hal ini lebih diperlukan lagi dalam rangka mengimplementasikan berbagai paradigma pendidikan baru pada era otonomi daerah seperti saat ini.

Program pembinaan guru dan personil pendidikan sebagaimana dikemukakan di atas lazim disebut sebagai supervisi pendidikan, yang merupakan suatu rangkaian dari kegiatan manajemen pendidikan. Untuk itu, para pembina dan kepala sekolah perlu memiliki pemahaman tentang supervisi, baik yang menyangkut pengertian, hakikat, tujuan, dan fungsi maupun teknik melakukan supervisi agar mereka dapat 
melakukannya dengan tepat. Dalam hal ini supervisi pendidikan dapat dimaknai sebagai kegiatan pemantauan oleh pembina dan kepala sekolah terhadap pelaksanaan kurikulum, penilaian kegiatan belajar-mengajar di kelas, pelurusan penyimpangan, peningkatan keadaan, perbaikan program, dan pengembangan kemampuan profesional guru. Kepala Sekolah merupakan motor penggerak, penentu arah kebijakan sekolah, memegang tugas dan tanggung jawab sebagai supervisor pendidikan di sekolah dimana kepala sekolah akan sangat menentukan bagaimana tujuan-tujuan sekolah dan pendidikan pada umumnya direalisasikan.

Menurut Carter Good's Dictionary of Education (dalam E. Mulyasa) mempunyai arti :

Segala usaha pejabat sekolah dalam memimpin guru-guru dan tenaga kependidikan lainnya, untuk memperbaiki pengajaran; termasuk menstimulasi, menyeleksi pertumbuhan dan perkembangan jabatan guru-guru, menyeleksi, dan merevisi tujuan-tujuan pendidikan, bahan pengajaran dan metode-metode mengajar serta evaluasi pengajaran.

Berkaitan dengan hal tersebut di atas maka teknik-teknik supervisi yang lazim dilakukan oleh kepala sekolah meliputi kegiatan : Kunjungan dan observasi kelas; Pembicaraan individual; Diskusi kelompok; Demonstrasi mengajar; dan Perpustakaan profesional. Indikator keberhasilan kegiatan supervisi tersebut dapat dilihat pada frekuensi kepala sekolah melakukan sipervisi dan mutu pendidikan yang dicapai oleh sekolah melalui prestasi belajar peserta didiknya.

Kondisi obyektif yang terjadi di SDN Uwedikan Kecamatan Luwuk Timur menunjukkan bahwa pelaksanaan supervisi kurang dilaksanakan oleh kepala sekolah sehingga terkadang guru masuk kelas untuk mengajar tidak disertai dengan penyusunan program satuan pelajaran (SP), selain itu, metode mengajar yang dilakukan oleh guru di kelas tidak terpantau dengan baik. Akibatnya, perencanaan proses belajar mengajar kurang dapat berjalan dengan baik. Kondisi tersebut tentu saja akan memberikan dampak kepada upaya peningkatan mutu pendidikan di sekolah yang bersangkutan.

\section{METODE PENELITIAN}

Penelitian ini dilaksanakan di SDN Inpres Uwedikan Kecamatan Luwuk Timur. Lokasi penelitian ditetapkan dengan dasar pertimbangan bahwa SDN Uwedikan Kecamatan Luwuk Timur dianggap cukup memadai untuk diteliti sesuai dengan judul penelitian ini karena pelaksanaan supervisi pendidikan di sekolah tersebut belum dilaksanakan sebagaimana mestinya oleh kepala sekolah. Variabel yang digunakan dalam penelitian ini ada dua macam variabel yaitu variabel bebas dan variabel terikat. Pelaksanaan Supervisi kepala sekolah ditempatkan sebagai variabel bebas (X) dan guru kelas sebagai variabel terikat (Y).

Sehubungan dengan jumlah populasi dibawah seratus orang maka penelitian ini merupakan penelitian populasi. Sehingga sampel akan diambil dari seluruh populasi yang ada, yaitu sebanyak 6 orang. Melalui teknik ini penulis mengadakan dialog secara langsung untuk memperoleh informasi dari peserta didik terpilih dalam menghimpun 
informasi yang relevan dengan judul penelitian. Teknik ini merupakan teknik pengumpulan data melalui formulir-formulir yang berisi pertanyaan-pertanyaan yang diajukan secara tertulis kepada responden untuk memilih salah satu alternatif atau bersifat multiple choice pada jawaban yang telah disediakan oleh peneliti. Setiap item pertanyaan berisi pernyataan positif. Skor untuk pernyataan ini adalah skor tertinggi yaitu 4 (empat) pada daerah jawaban nomor 1 (satu) dan yang terendah mempunyai skor 1 pada daerah jawaban nomor 4 (empat). Pemberian bobot untuk setiap jawaban menggunakan Skala Likert, berbentuk nomor urut 1-4 dengan alternatif sebanyak 4 (empat) item.

\section{HASIL DAN PEMBAHASAN}

Data yang disajikan dalam bab ini adalah hasil penelitian dari penyebaran angket kepada guru kelas, di SDN Uwedikan Kecamatan Luwuk Timur Kecamatan Luwuk Timur Kabupaten Banggai Kepulauan. Untuk mengolah data di atas, digunakan analisis persentase berdasarkan jawaban yang diberikan oleh responden, kemudian disajikan dalam bentuk tabel distribusi frekuensi.

\section{Pelaksanaan Supervisi Kepala Sekolah}

Berkaitan dengan pola pengelolaan pendidikan saat ini, supervisi lebih ditekankan pada pembinaan dan peningkatan kemampuan kinerja tenaga pendidik di sekolah dalam melaksanakan tugas. Untuk memperoleh pemahaman dan wawasan yang lebih luas tentang apa sebenarnya supervisi itu.

Berdasarkan hasil penelitian ditampilkan rekapitulasi tentang pelaksanaan supervisi di SDN Uwedikan Kecamatan Luwuk Timur dapat dilihat pada Tabel 1 berikut :

Tabel 1. Rekapitulasi Hasil Angket Pelaksanaan Supervisi Kepala Sekolah Di SDN Uwedikan Kecamatan Luwuk Timur.

\begin{tabular}{cccccccccccccc}
\hline No & \multicolumn{10}{c}{ Jawaban Respoden Untuk Item } & Jum. & \multicolumn{2}{c}{ Rata - } \\
& \cline { 2 - 10 } & $(1)$ & $(2)$ & $(3)$ & $(4)$ & $(5)$ & $(6)$ & $(7)$ & $(8)$ & $(9)$ & $(10)$ & & Rata \\
\hline 1 & 4 & 4 & 4 & 4 & 4 & 4 & 4 & 3 & 4 & 4 & 40 & 4 \\
2 & 4 & 4 & 4 & 4 & 4 & 3 & 4 & 4 & 4 & 4 & 39 & 3,9 \\
3 & 4 & 4 & 3 & 4 & 4 & 4 & 4 & 4 & 3 & 4 & 38 & 3,8 \\
4 & 4 & 4 & 4 & 3 & 4 & 4 & 4 & 4 & 4 & 4 & 39 & 3,9 \\
5 & 4 & 4 & 4 & 4 & 4 & 4 & 4 & 2 & 4 & 4 & 38 & 3,8 \\
6 & 4 & 4 & 3 & 4 & 4 & 4 & 4 & 4 & 3 & 4 & 38 & 3,8 \\
\hline Jum & 24 & 24 & 22 & 23 & 24 & 23 & 24 & 21 & 22 & 24 & 232 & 23,2 \\
\hline Skor & 4 & 4 & 3,67 & 3,8 & 4 & 3,8 & 4 & 3,5 & 3,67 & 4 & 38,6 & 3,86 \\
\hline$\%$ & 100 & 100 & 91,7 & 95 & 100 & 95 & 100 & 87,5 & 91,7 & 100 & 96,5 & 96,5 \\
\hline
\end{tabular}

Sumber : Data Primer Tahun 2013

Berdasarkan rekapitulasi pada Tabel 1 tersebut di atas tentang peranan guru sebagai menejer dalam pengelolaan kelas di SDN Uwedikan Kecamatan Luwuk Timur adalah "sangat memuaskan" dengan perolehan skor rata - rata 3,86. Skor tersebut memberi makna bahwa 96,5\% atau 5 orang dari 6 orang responden yang menyatakan bahwa pelaksanaan supervisi Kepala sekolah di SDN Uwedikan Kecamatan Luwuk adalah " sangat memuaskan " 


\section{Aspek Guru Kelas}

Masyarakat menempatkan guru pada tempat yang lebih terhormat di lingkungannya karena dari seorang guru diharapkan masyarakat dapat memperoleh ilmu pengetahuan. Ini berarti bahwa guru berkewajiban mencerdaskan bangsa menuju pembentukan manusia Indonesia seutuhnya yang berdasarkan Pancasila, oleh sebab itu guru merupakan profesi/jabatan atau pekerjaan yang memerlukan keahlian khusus sebagai guru. Jenis pekerjaan ini tidak dapat dilakukan oleh sembarang orang diluar kependidikan walaupun kenyataannya masih dilakukan oleh orang diluar kependidikan.

Berdasarkan hasil penelitian ditampilkan rekapitulasi tentang guru kelas di SDN Uwedikan Kecamatan Luwuk Timur dapat di lihat pada Tabel 2 berikut :

Tabel 2 : Rekapitulasi Hasil Angket Guru Kelas Di SDN Uwedikan Kecamatan Luwuk Timur

\begin{tabular}{ccccccccccccc}
\hline & \multicolumn{10}{c}{ Jawaban Respoden Untuk Item } & Jum. & Rata - \\
\cline { 2 - 9 } No & $(11)$ & $(12)$ & $(13)$ & $(14)$ & $(15)$ & $(16)$ & $(17)$ & $(18)$ & $(19)$ & $(20)$ & & Rata \\
\hline 1 & 4 & 4 & 4 & 4 & 4 & 3 & 4 & 4 & 4 & 3 & 38 & 3,8 \\
2 & 3 & 4 & 4 & 3 & 4 & 4 & 4 & 2 & 4 & 4 & 36 & 3,6 \\
3 & 4 & 3 & 4 & 4 & 4 & 4 & 4 & 3 & 4 & 4 & 38 & 3,8 \\
4 & 2 & 4 & 4 & 4 & 3 & 4 & 4 & 4 & 3 & 4 & 36 & 3,6 \\
5 & 4 & 4 & 4 & 4 & 4 & 4 & 3 & 4 & 4 & 2 & 37 & 3,7 \\
6 & 4 & 4 & 4 & 4 & 4 & 4 & 4 & 4 & 4 & 4 & 40 & 4 \\
\hline Jum & 21 & 23 & 24 & 23 & 23 & 23 & 23 & 21 & 23 & 21 & 225 & 22,5 \\
\hline Skor & 3,5 & 3,8 & 4 & 3,8 & 3,8 & 3,8 & 3,8 & 3,5 & 3,8 & 3,5 & 37,5 & 3,75 \\
\hline$\%$ & 87,5 & 95 & 100 & 95 & 95 & 95 & 95 & 87,5 & 95 & 87,5 & 93,75 & 93,75 \\
\hline
\end{tabular}

Sumber : Data Primer Tahun 2013

Berdasarkan rekapitulasi pada tabel 2 tersebut di atas tentang guru kelas di SDN Uwedikan Kecamatan Luwuk Timur adalah " sangat memuaskan "dengan perolehan skor rata - rata 3,75. Skor tersebut memberi makna bahwa 93,75\% atau 5 dari 6 orang responden yang menyatakan bahwa guru kelas di SDN Uwedikan Kecamatan Luwuk Timur adalah " sangat memuaskan "

Berdasarkan hasil analisis data tersebut di atas, data yang dipaparkan mengenai pelaksanaan supervisi kepala sekolah terhadap guru kelas di SDN Uwedikan Kecamatan Luwuk Timur yang ditinjau dari dua aspek kemudian penulis jabarkan dalam tabel berikut yang hasilnya merupakan kesimpulan dari keseluruhan aspek yang dikaji. Tabel yang akan disajikan merupakan rekapitulasi dari keseluruhan angket yang telah disebarkan kepada responden. Secara lengkap rekapitulasi hasil angket tersebut penulis sajikan dalam Tabel 3 berikut ini.

Tabel 3: Rekapitulasi Hasil Angket Tentang Pelaksanaan Supervisi Kepala Sekolah Terhadap Guru Kelas.

\begin{tabular}{clcc}
\hline No & \multicolumn{1}{c}{ Aspek } & Skor & Presentase \\
\hline \multirow{2}{*}{1} & $\begin{array}{l}\text { Aspek Pelaksanaan Supervisi Kepala } \\
\text { sekolah }\end{array}$ & 3,86 & 96,5 \\
\hline $2 \quad$ Aspek Guru kelas & 3,75 & 93,75 \\
\hline Total & 7,61 & 190,25 \\
\hline Rata - Rata & 3,80 & 95.125 \\
\hline Sumber : Data Primer Tahun 2013 & &
\end{tabular}

Dari Tabel 3 tersebut di atas dapat diketahui bahwa responden menyatakan bahwa pelaksanaan supervisi kepala sekolah terhadap guru kelas di SDN Uwedikan 
Kecamatan Luwuk Timur tergolong "sangat memuaskan" dengan perolehan skor 3,80 . Skor tersebut memberi makna bahwa 95,125\%, atau 5 orang dari 6 responden menyatakan bahwa pelaksanaan supervisi kepala sekolah terhadap guru kelas di SDN Uwedikan Kecamatan Luwuk Timur adalah "sangat memuaskan".

\section{KESIMPULAN}

Berdasarkan hasil analisis data tersebut di atas, data yang dipaparkan mengenai pelaksanaan supervisi kepala sekolah terhadap guru kelas di SDN Uwedikan Kecamatan Luwuk Timur dapat disimpulkan bahwa secara keseluruhan, responden menyatakan Peranan guru dalam menerapkan pembelajaran yang berhasil di SDN Uwedikan tergolong "sangat memuaskan" dengan perolehan skor 3,80. Skor tersebut memberi makna bahwa 95,125\%, atau 5 orang dari 6 responden menyatakan bahwa pelaksanaan supervisi kepala sekolah terhadap guru kelas di SDN Uwedikan Kecamatan Luwuk Timur adalah "sangat memuaskan".

\section{DAFTAR PUSTAKA}

Anas Sudijono, 2003, Pengantar Statistik Pendidikan, PT. Raja Grafindo Persada, Jakarta.

A. M. Sardiman, 1992, Interaksi dan Motivasi Belajar Mengajar, Rajawali Press, Jakarta.

Henry N. Siahaan, 1992, Peranan Ibu Bapak Mendidik Anak, Angkasa, Bandung.

M. Diah, 1983, Mewujudkan Prestasi Belajar, Depdikbud, Jakarta.

Slameto, 1991, Belajar dan Faktor-Faktor Yang Mempengaruhinya, Rineka Cipta, Jakarta.

Suharsimi Arikunto, 1990, Prosedur Penelitian, Suatu Pendekatan Praktek, PT. Bina Angkasa, Jakarta.

Sumadi Suryabrata, 1983, Metodelogi Penelitian, CV. Rajawali, Jakarta.

Usman, Moh. Uzer, 2002, Menjadi Guru Profesional, PT. Remaja Rosdakarya, Bandung.

Winarno Surachmad, 1985, Pengantar Penelitian Ilmiah, Dasar, Metode dan Teknik, Tarsito, Bandung. 